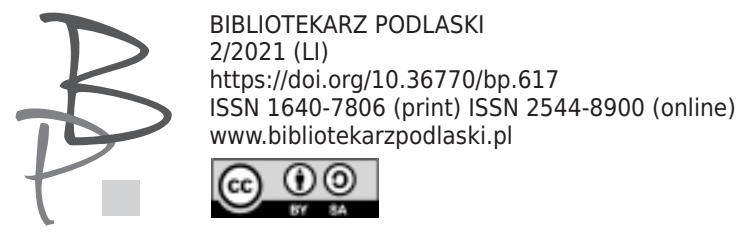

\author{
Jarosław Ławski* \\ Uniwersytet w Białymstoku, Polska / University of Białystok, Poland \\ ORCID: 0000-0002-1167-5041

\section{Jubileusz 70. urodzin Jana Leończuka, Białystok, 24 czerwca 2020 r. Sprawozdanie}

\author{
Celebrating the $70^{\text {th }}$ Birthday of Jan Leończuk, \\ Bialystok, 24 June 2020. Report
}

Jan Leończuk (ur. 24 czerwca 1950 w Łubnikach) to niewątpliwie jedna z najwyrazistszych postaci kultury polskiej na Podlasiu: poeta, prozaik, wieloletni dyrektor Książnicy Podlaskiej im. Łukasza Górnickiego, autorytet życia literackiego. Debiut Leończuka w latach 70 . XX wieku odbił się szerokim echem w ówczesnej poezji polskiej, recenzowany był przez najważniejszych krytyków epoki1 ${ }^{1}$. Pięćdziesiąt lat pracy (1970-2020) ugruntowało pozycję Leończuka w życiu literackim i kulturalnym. Twórcę kilkakroć fetowano jubileuszami, uczczono potężną 972-stronicową księgą zatytułowaną Bibliotheca mundi², a na końcu, na swe 70. urodziny, poeta otrzymał dary szczególne.

\footnotetext{
* Jarosław Ławski - prof. dr hab., kierownik Katedry Badań Filologicznych „Wschód - Zachód" na Wydziale Filologicznym Uniwersytetu w Białymstoku. Autor wielu książek, m.in. Mickiewicz - Mit - Historia. Studia (Białystok 2010); Miłosz: „Kroniki” istnienia. Sylwy (Białystok

1 Zob. J. Leończuk, Rachunek, Białystok 1973; tegoż, Żalnik, Olsztyn 1979; tegoż, Duszna noc, Wrocław 1981.

2 Bibliotheca mundi. Studia bibliologiczne ofiarowane Janowi Leończukowi, red. J. Ławski, Ł. Zabielski, Białystok 2016, ss. 972.
} 2014). 
24 czerwca 2020 roku zorganizowano okazały Jubileusz 70-lecia Jana z Łubnik pod Zabłudowem. Kulminacyjnym punktem Jubileuszu była uroczystość w auli Książnicy Podlaskiej (przypomnijmy, że to z inicjatywy Leończuka Bibliotekę Wojewódzką przekształcono w Książnicę Podlaską). Jej momentem szczególnym była prezentacja dwóch ogromnych tomów Poezji zebranych Jana Leończuka, opracowanych i poprzedzonych wstępami przez Jarosława Ławskiego i Dariusza Kuleszę 3 . Publikowane tomy otwierają zupełnie nową Serię Naukową „Pisarze Podlasia i Kresów”, w której w kolejności ukażą się poezje zebrane Wiesława Kazaneckiego i pisma literackie Aleksandry Nowackiej.

Uroczyste posiedzenie odbyło się bez udziału Jubilata, od kilku lat przykutego chorobą do łoża. Odbyło się też w szczególnych warunkach pandemii koronawirusa. Zdecydowano się jednak na tradycyjne spotkanie, a nie wydarzenie online. Miało więc ono specyficzny kształt: ograniczono liczbę gości, którzy w maseczkach siedzieli w półtorametrowych odstępach.

Była to uroczystość niezwykle udana - także dlatego, że miłośnicy literatury spragnieni byli spotkania na żywo. Jubileusz Jana Leończuka zorganizowały wspólnie: Książnica Podlaska im. Łukasza Górnickiego, Wydział Filologiczny Uniwersytetu w Białymstoku, Polskie Radio Białystok, a patronat medialny sprawowały „Kurier Poranny”, TVP3 Białystok i „Gazeta Wyborcza" w Białymstoku.

Uroczystość o 14.30 rozpoczęła dyr. Jolanta Gadek, która powitała gości i przedstawiła sylwetkę Jubilata w Galerii Parter Książnicy Podlaskiej, gdzie odbył się wernisaż fotografii Anny Worowskiej „Radość życia”. Autorka pięknych zdjęć podlaskich krajobrazów i przyrody po krótkim przemówieniu poprosiła red. Krzysztofa Kurianiuka o zabranie głosu, odczytanie fragmentu prozy Leończuka z tomu o Zabłudowie ${ }^{4}$. Wśród gości wernisażu wymieńmy: dr Martę Białobrzeską, red. Andrzeja Kalinowskiego, dr hab. Krzysztofa Korotkicha, dr Zofię Redlarską-Olek, red. Dorotę Sokołowską, mgra Bernarda Zabielskiego, ks. dra Dariusza Wojteckiego, panią Bogusławę Wencław i prof. Dariusza Kuleszę.

3 J. Leończuk, Poezje zebrane, T. I: 1970-1997, wstęp J. Ławski, red. naukowa J. Ławski, D. Kulesza, współpraca red. M. Olesiewicz, Białystok 2020, ss. 553; T. II: 1998-2019, wstęp D. Kulesza, red. J. Ławski, D. Kulesza, współpraca red. M. Olesiewicz, Białystok 2020, ss. 788.

4 Zob. Ziemia Zabludowska. Legenda-Historia-Przyroda, fot. A. Worowska, teksty i red. J. Leończuk, Białystok 2014. 


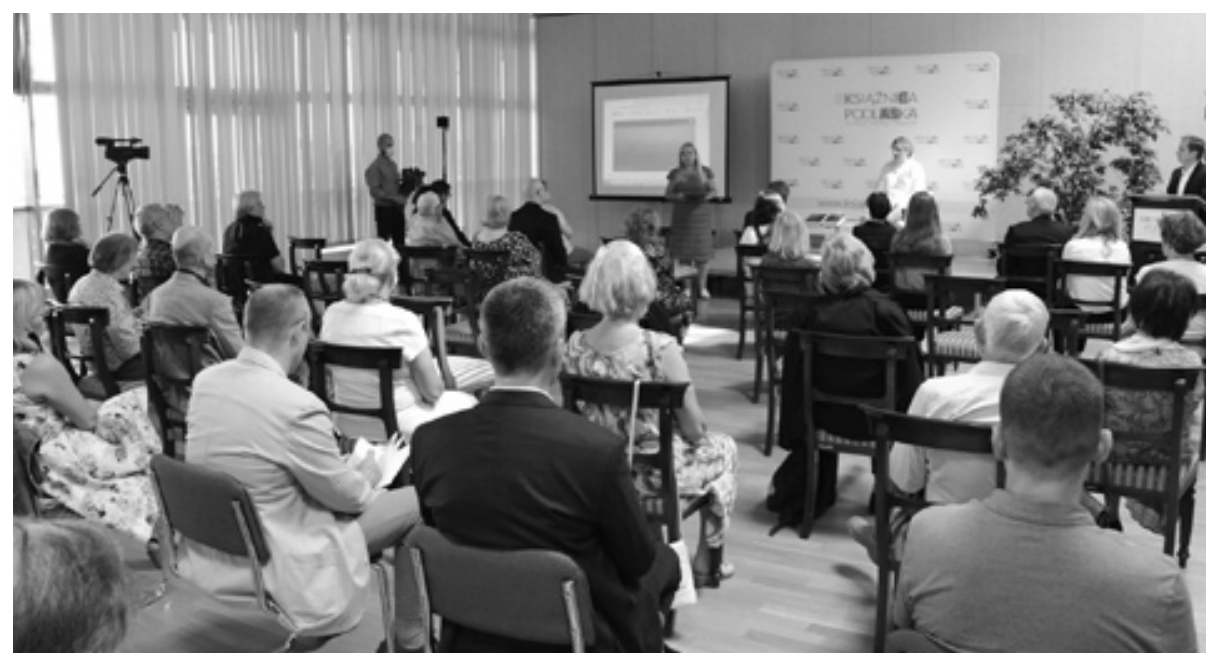

Jubileusz urodzin Jana Leończuka, otwarcie wydarzenia przez dyr. Jolantę Gadek, fot. B. Maleszewska-Oksztol

Po wernisażu rozpoczęła się w auli na VI piętrze część właściwa Jubileuszu, którą poprowadził Dominik Sołowiej. Odczytano listy gratulacyjne, m.in. od europosła Krzysztofa Jurgiela i Marszałka Województwa Podlaskiego Artura Kosickiego ${ }^{5}$.

Z kolei głos zabrał prof. Jarosław Ławski, inicjator wydania Poezji zebranych Jana Leończuka. Podziękował on w sposób szczególny osobom zaangażowanym w wydanie obu tomów: Żonie poety, Barbarze, która wspierała wydawców; władzom miasta Zabłudowa, które wsparły edycję finansowo, reprezentowanym przez pana Wiesława Dąbrowskiego; śp. panu Markowi Olesiewiczowi, regionaliście i poecie z Knyszyna, komputerowo redagującemu najpierw to dzieło (śp. Marek Olesiewicz zginął tragicznie w 2018 roku w wypadku drogowym) ${ }^{6}$. Edytor wskazał na zasługi członków Komitetu Naukowego Edycji Poezji zebranych Jana Leończuka: Józefa Zenona Budzińskiego - poety, przyjaciela Jubilata, Państwa Grażyny i Ireneusza Da-

5 Zabrakło na uroczystości przedstawicieli miasta Białystok, prezydenta Białegostoku. A przecież Jan Leończuk to trzykrotny Laureat Nagrody Literackiej Prezydenta Miasta Białegostoku im. Wiesława Kazaneckiego w 1991, 1996, 2010 roku.

6 Zob. M. Olesiewicz, Poezja Jana Leończuka w oczach krytyki literackiej. Rekonesans, [w:] Bibliotheca mundi..., dz. cyt., s. 91-113. 
widowiczów - przyjaciół, dyr. Jolanty Gadek - następczyni Jana Leończuka w kierowaniu Książnicą, dr hab. Anny Janickiej, prof. UwB - zaprzyjaźnionej z Leończukami badaczki literatury, prof. Dariusza Kuleszy - redaktora i autora wstępu, red. Mariusza Śliwowskiego - wydawcy i przyjaciela pisarza, dr Anny Worowskiej - biologa i znakomitego fotografa, dra Łukasza Zabielskiego kierownika Działu Naukowego, który w Książnicy Podlaskiej mógł kształtować swój warsztat edytora dzięki zainicjowanej przez Leończuka edycji Pism rozproszonych Zygmunta Glogera, dra hab. Krzysztofa Korotkicha - badacza, współpracownika Jubilata.

Prof. Ławski przypomniał zasługi Poety7, lecz nade wszystko wskazał na pożytki płynące z zebrania wszystkich znanych wierszy Leończuka. Podkreślił, że taka edycja - o ściśle naukowym charakterze - jest swoistym przełamaniem niemocy lokalnych środowisk, gdzie tak wielu aspiruje do palmy pierwszeństwa, iż zazwyczaj nikt nie jest w stanie uczynić kroku oddalającego kompleks prowincjonalności. Kompleks ów przełamuje osobliwy „list do przyszłości”, jakim są poezje zebrane każdego liryka. Na początku i końcu laudacji mówca zwrócił się bezpośrednio do Poety, posyłając Mu, jak mówił, „dwa dobre duchy: poezji i naszej modlitwy". Przekazał też na ręce siostrzenicy poety gorące pozdrowienia autorowi Żalnika i jego Rodzinie.

Następnie głos zabrał przyjaciel-liryk Józef Zenon Budziński, podkreślając w emocjonalnych słowach dobroć Jubilata. Red. Krzysztof Kurianiuk wspominał radiowe dzieje Zapiśników Leończuka. W przerwach między wystąpieniami wiersze poety czytał Eligiusz Buczyński (z tomu Za horyzontem, Białystok 1986). Uczestnicy spotkania wysłuchali teledysku z muzyką do słów Leończuka rapowego artysty Lukasyno, a także obejrzeli fragmenty filmu Bożeny Bednarek pt. Spotkanie z Janem Leończukiem. Na końcu spotkania o głos poprosił twórca Ludowy Zbigniew Nasiadko, który wzruszająco zaśpiewał a capella wiersz Leończuka, nagrodzony wielkimi brawami.

7 Jan Leończuk przekształcił Bibliotekę Wojewódzką w nowoczesną Książnicę, zdobył dla niej i utrzymał statut biblioteki naukowej otrzymującej egzemplarz obowiązkowy, powołał i przekształcił „Bibliotekarza Podlaskiego” w nowoczesne pismo naukowe z listy MNiSW, redagował almanach „Epea”, zainicjował wydawanie Pism rozproszonych Zygmunta Glogera i licznych monografii naukowych, uruchomił „Środy Literackie”, powołał Dział Naukowy Książnicy, nawiązał współpracę z bibliotekami Wilna, Kłajpedy, Grodna, Mińska, Lwowa. Za swe zasługi literackie otrzymał w 2003 roku Ogólnopolską Nagrodę Literacką im. Franciszka Karpińskiego. 


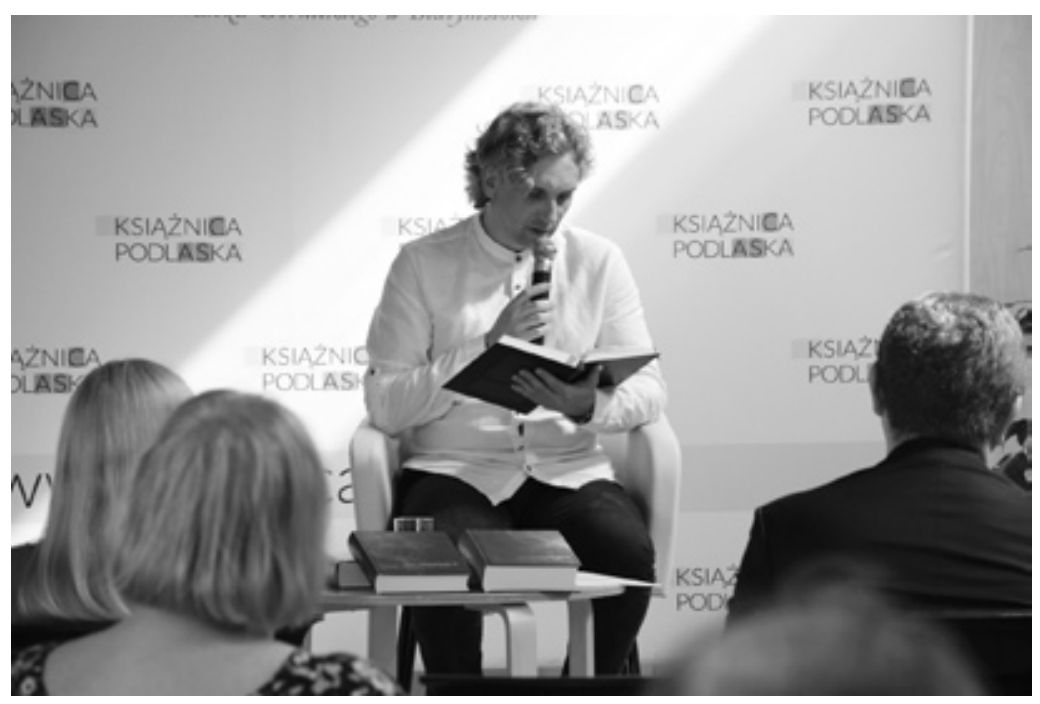

Eligiusz Buczyński (Książnica Podlaska) czyta wiersze Jubilata, fot. B. Maleszewska-Oksztol

Na sali spotkaliśmy podczas Jubileuszu między innymi pana Mirosława Bielawskiego (Polskie Radio Białystok), prof. Violettę Wejs-Milewską z mężem Edwardem, dra Łukasza Zabielskiego, red. Dorotę Sokołowską.

Po uroczystości, część gości udała się do Kościoła pw. Św. Kazimierza Królewicza, gdzie o godz. 18.00 odprawiono mszę św. w intencji Jubilata. Po mszy wysłuchano recitalu organowego prof. Józefa Kotowicza oraz recytacji wierszy Leończuka w wykonaniu dziennikarzy radiowych: Doroty Sokołowskiej i Krzysztofa Kurianiuka.

Wypada podkreślić z uznaniem, że (z wyjątkiem władz miasta Białegostoku) Jubileusz Jana Leończuka spotkał się z nadzwyczajnym odzewem różnych środowisk kulturalnych, społecznych, dziennikarskich i politycznych, które połączyło uznanie dla dokonań Wybitnej Osobowości.

Polskie Radio Białystok wyemitowało (26.06, 9.00-13.00) Cztery opowieści o Jubilacie, TVP Białystok reportaż Alicji Grzechowiak Jan z Łubnik (24.06, 14.40), zaś PR Białystok audycję Doroty Sokołowskiej Jan 70 (24.06, 17.15 i 22.15). W lokalnej „Gazecie Wyborczej” ukazał się artykuł Moniki Żmijewskiej Zapiśniki, frazy i tęsknoty pana Jana. Jubileusz Jana Leończuka (19.06.2020). „Kurier Poranny” informował o wszystkim obszernie piórem 


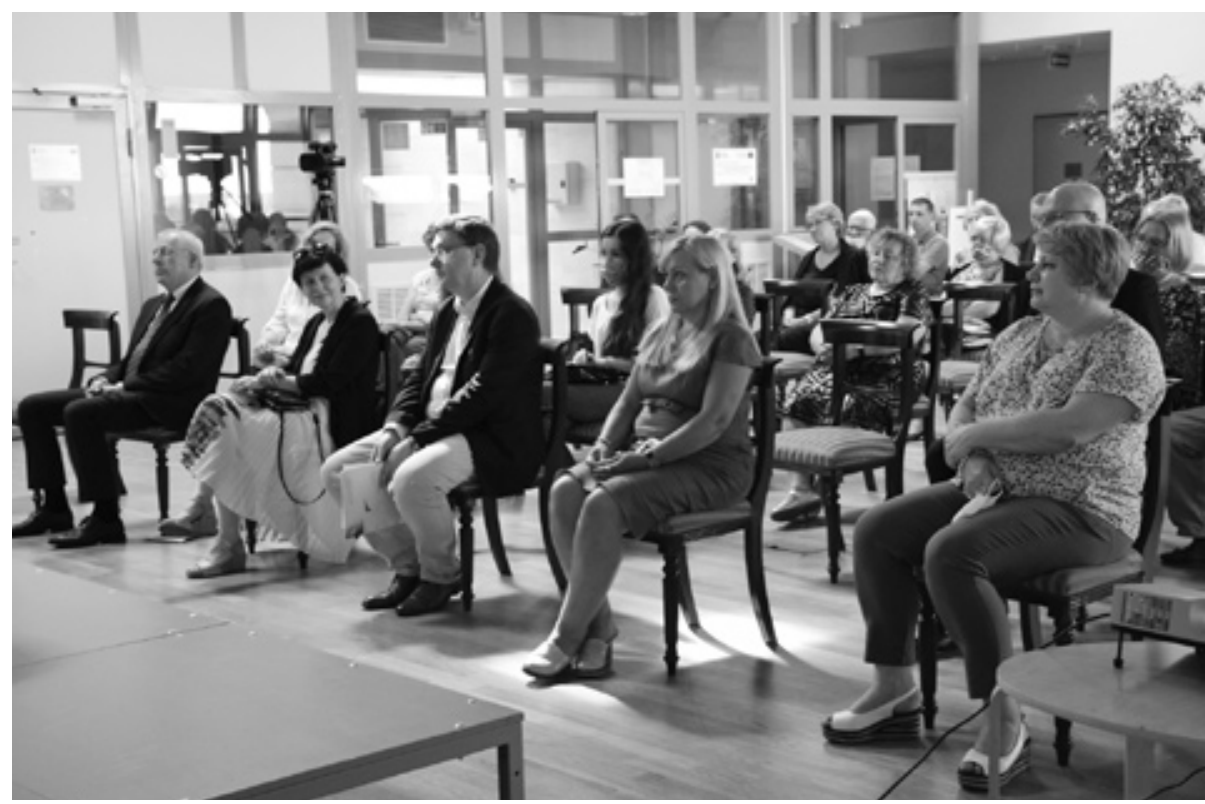

Uczestnicy Jubileuszu urodzin Jana Leończuka, od lewej: Krzysztof Kurianiuk, prof. Anna Janicka, prof. Jarosław Ławski, dyr. Jolanta Gadek, dyr. Dorota Łuckiewicz; fot. B. Maleszewska-Oksztolf

Jerzego Doroszkiewicza w artykule Jan Leończuk 24 czerwca będzie obchodzit 70. urodziny. Jana $z$ Lubnik świata przywracanie. $W$ 70. urodziny poety $i$ piszacych przyjaciela (22.06.2020). Krystyna Konecka, poetka i dziennikarka, uczciła Jubilata Jubileuszem Jana Leończuka (Pisarze.pl, 23.06.2020)8. Wszystkie media lokalne uhonorowały Dobrego Człowieka z Łubnik. Artykuł autorstwa prof. Zbigniewa Chojnowskiego poświęcony jego Poezjom zebranym ukazał się w „Nowych Książkach”.

Można powiedzieć, że zaczęło się przywracanie miejsca w polskiej kulturze (a nie tyko kulturze „regionalnej”) Poecie, który świadomie wybrał na początku XXI stulecia strategię wycofania się z życia literackiego. Wybrał kontemplację istnienia.

8 Dodajmy, że o święcie Jana z Łubnik informowały: wrotapodlasia.pl (Potrójne święto Jana Leończuka; 24.06.2020); www.radio.bialystok.pl (70 lat Jana Leończuka, 24.06.2020); podlaskisenior.pl (Poetyckie zadziwienia nad światem Jana Leończuka, 24.06.2020).

9 Z. Chojnowski, Liryczny zawrót głowy, „Nowe Książki” 9/2020. 
Wraz z Krzysztofem Korotkichem odwiedziliśmy Jana z Łubnik następnego dnia (25.06) tuż po południu. W Łubnikach jak zawsze śpiewały ptaki, dwa wielkie koty przywitały nas na ganku domu. Odeszły w przeszłość pamiętne uczty na św. Jana odbywające się w domu obok wypełnionym rzeźbami i obrazami ludowych artystów. Jan, przykuty do łoża, wspierany przez żonę Barbarę, patrzył na nas tymi samymi oczami pełnymi dobra i rozumienia.

Zapytany, czy wiersze przychodzą jeszcze do niego, z radością odszepnął: „Już nie...”. 